\title{
MANUFACTURING CAPACITY MANAGEMENT BY USING MODERN SIMULATION TOOLS
}

\author{
doi: 10.2478/czoto-2021-0014
}

Date of submission of the article to the Editor: 13/12/2020

Date of acceptance of the article by the Editor: 3/03/2021

\author{
Marek Krynke ${ }^{1}$ - orcid id: 0000-0003-4417-1955 \\ ${ }^{1}$ Czestochowa University of Technology, Poland
}

\begin{abstract}
Determining the parameters of the production system as well as the choice of the type of manufactured elements flow shall appoint the level of effectiveness of the manufacturing process. The article presents an example of implementation the simulation verification process of the production flow, taking into account system constraints. The basic stages of developing a simulation model in this process are discussed, taking into account the necessary information and input data. The results show the impact of the application selected flow scenarios on the level of generated costs and the duration of the manufacturing process. The process of assessing individual variants of the organization production was performed on the basis of the results obtained by computer simulation in the FlexSim simulation software.
\end{abstract}

Keywords: computer simulation, production processes, FlexSim, improvement

\section{INTRODUCTION}

The development of modern computer technology, especially in the field of production engineering, has resulted in the emergence of the digital factory concept, understood as an entity representing a virtual reflection of real production processes. This concept is a direct result of the evolution CAD (Computer Aided Design), CAM (Computer Aided Manufacturing) systems, integrated enterprise management systems (ERP / ERP II) and the need to reduce the costs of designing and implementing production systems. Thanks to the use of comprehensive IT solutions in the field of modeling and simulation of manufacturing processes, a significant economic benefit is achieved, especially in mass production (Herma, 2011; Le et al., 2020).

This is why there are more IT solutions in the area of tracking, monitoring and visualizing the course of production processes in real time. The effectiveness of the production planning and scheduling processes, in particular at the stage of simulating virtual models of a digital factory, depends primarily on the mathematical models and optimization algorithms used (Świder and Zdanowicz, 2005). In complex production systems, this efficiency is translated primarily into achieving a lower level of production costs, shorter production cycle times with high data processing efficiency at the same time. It is also desirable that the digital model reacts quickly to changes (Herma, 2011; Klimecka-Tatar, 2018). 
The methods of development and product management are a consequence of the modern market, which requires the supplier to act quickly and flexibly, as well as a fast and flexible offer adapted to the current customer needs (Bartnicka et al., 2020; Fila et al., 2020; Gola and Korzan, 2011; Kapustka, et al., 2020; Ulewicz and Mazur, 2019). Additionally, it requires simultaneous processing of information, communication and coordination of activities (Krynke and Mielczarek, 2018). The above-mentioned elements make companies more and more often using IT tools supporting the processes taking place within their internal activities (Jakubowski and Weretko, 2010). One of them, presented in this paper, is FlexSim. FlexSim simulation program is used primarily for modeling, simulation and visualization of business processes (Beaverstock et al., 2012; Krenczyk, 2018). Importantly, it can help to solve inventory and work in progress(WIP) problems, to optimize the production line, to determine business performance, to manage bottlenecks, to test new planning practices, to justify productivity and capital expenditure (Gołda and Kampa, 2009).

FlexSim allows realizing and animate 3D models and to create models directly using $\mathrm{C}++$. It is supported by simulation and graphic libraries (Leks and Gwiazda, 2015; Cegłowski, C., 2006).

\section{PRELIMINARY ASSUMPTIONS FOR THE CONSTRUCTION A SIMULATION MODEL OF THE PRODUCTION LINE}

The subject of the research described in the article was evaluate in the various variants of the organization of the production cycle. The production process of gears (Fig. 1), carried out in a production plant specializing in the production of machine components, was analyzed.

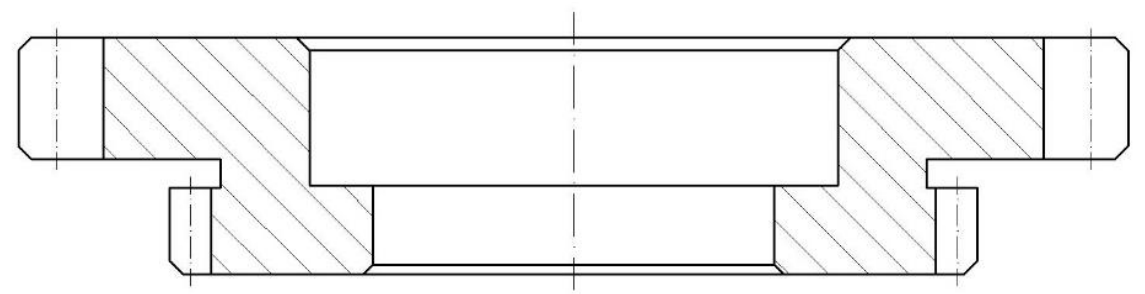

Source: own study

Fig. 1. Manufactured detail - gear wheel

In order to obtain the results necessary to perform the analysis, a model reflecting the considered process was built in the FlexSim simulation software. Depending on the type of material flow used and the size of the batch (determined by the size of the order), the parameters generated by the analyzed process (production duration, level of generated costs) were verified. As a result of the computer simulation, the results were obtained, enabling the selection of the best flow organization among the tested variants (ensuring the reduction of production time and costs).

At the initial stage of creating the simulation model, assumptions were made regarding the considered manufacturing process, i.e. (Pawlak and Nowacki, 2017):

- the built model included the production process of the detail for three batches sizes: 1,10 and 100 pieces,

- three types of flow have been verified: series, parallel and series-parallel, 
- the production process included making only one series of elements of the selected type,

- failure frequency of individual production stands has not been taken into account and the fact of possible delays caused by random events has been ignored.

In order to map the existing production process, sets of the following values have been established: input (type and time of material flow), output (time of making a specific batch of elements), fixed (type and time of performing technological operations as well as used production stations and their arrangement).

Table 1 summarizes the data on the duration of individual technological operations, process routes and positions on which the selected operation will be performed.

Table 1

List of technological operations

\begin{tabular}{|c|c|c|c|c|}
\hline $\begin{array}{c}\text { Operati- } \\
\text { on } \\
\text { number }\end{array}$ & Type of operation & $\begin{array}{c}\text { Workstation, } \\
\text { type of transport }\end{array}$ & $\begin{array}{c}\text { Process } \\
\text { time } \\
\text { [minutes] }\end{array}$ & $\begin{array}{c}\text { Distance } \\
\text { [m] }\end{array}$ \\
\hline $\mathbf{1 .}$ & Raw material storage & Queue & - & - \\
\hline $\mathbf{2 .}$ & Inter-departmental transport & Forklift & - & 50 \\
\hline $\mathbf{3 .}$ & Inter-operational storage & Queue & - & - \\
\hline $\mathbf{4 .}$ & Inter-workstations transport & Operator & - & 3.5 \\
\hline $\mathbf{5 .}$ & Cutting the material & Processor & 7.5 & - \\
\hline $\mathbf{6 .}$ & Inter-workstations transport & Operator & - & 3.5 \\
\hline $\mathbf{7 .}$ & Inter-operational storage & Queue & - & - \\
\hline $\mathbf{8 .}$ & Inter-workstations transport & Operator & - & 3.5 \\
\hline $\mathbf{9 .}$ & Drilling & Processor & 4.1 & - \\
\hline $\mathbf{1 0 .}$ & Inter-workstations transport & Operator & - & 3.5 \\
\hline $\mathbf{1 1 .}$ & Inter-operational storage & Queue & - & - \\
\hline $\mathbf{1 2 .}$ & Inter-workstations transport & Operator & - & 3.5 \\
\hline $\mathbf{1 3 .}$ & Turning & Processor & 11.0 & - \\
\hline $\mathbf{1 4 .}$ & Inter-workstations transport & Operator & - & 3.5 \\
\hline $\mathbf{1 5 .}$ & Inter-operational storage & Queue & - & - \\
\hline $\mathbf{1 6 .}$ & Inter-workstations transport & Operator & - & 3.5 \\
\hline $\mathbf{1 7 .}$ & Gear hobbing & Processor & 28.8 & - \\
\hline $\mathbf{1 8 .}$ & Inter-workstations transport & Operator & - & 3.5 \\
\hline $\mathbf{1 9 .}$ & Inter-operational storage & Queue & - & - \\
\hline $\mathbf{2 0 .}$ & Inter-workstations transport & Operator & - & 3.5 \\
\hline $\mathbf{2 1 .}$ & Gear chiselling & Processor & 21.3 & - \\
\hline $\mathbf{2 2 .}$ & Inter-workstations transport & Operator & - & 3.5 \\
\hline $\mathbf{2 3 .}$ & Inter-operational storage & Queue & - & - \\
\hline $\mathbf{2 4 .}$ & Inter-workstations transport & Operator & - & 3.5 \\
\hline $\mathbf{2 5 .}$ & The heat treatment & Processor & 10 & - \\
\hline $\mathbf{2 6 .}$ & Inter-workstations transport & Operator & - & 3.5 \\
\hline $\mathbf{2 7 .}$ & Inter-operational storage & Queue & - & - \\
\hline $\mathbf{2 8 .}$ & Inter-workstations transport & Operator & - & 3.5 \\
\hline $\mathbf{2 9 .}$ & Grinding & Processor & 7.0 & - \\
\hline $\mathbf{3 0 .}$ & Inter-workstations transport & Operator & - & 3.5 \\
\hline $\mathbf{3 1 .}$ & Inter-operational storage & Queue & - & - \\
\hline $\mathbf{3 2 .}$ & Inter-workstations transport & Operator & - & 3.5 \\
\hline $\mathbf{3 3 .}$ & Control & Processor & 5.0 & - \\
\hline $\mathbf{3 4 .}$ & Inter-workstations transport & Operator & - & 3.5 \\
\hline
\end{tabular}




\begin{tabular}{|c|c|c|c|c|}
\hline 35. & Completing products & Queue & - & - \\
\hline 36. & Inter-departmental transport & Forklift & - & 50 \\
\hline 37. & Finished products storage & Queue & - & - \\
\hline
\end{tabular}

Source: own study

The duration of technological operations presented in Table 1 covers the total duration of a given production operation (there is no division into unit and preparatory-completion time).In this process, there are 7 technological operations that add value to the product and there is one control operation. The others are storage and transport operations.

\section{CONSTRUCTION OF A SIMULATION MODEL WITH THE USE OF FLEXSIM SOFTWARE}

The task of the simulation model was to faithfully reproduce the analyzed production process. Therefore, it has become necessary to correctly model the entire simulation system, along with the determination of the relationships between individual objects and assigning them to characteristic quantities. The components included in the model included: source, 8 production stations, 8 operators, 10 inter-operational buffers, 1 buffer for defective products, 2 transporters and a warehouse for finished products. Figure 2 presents a model of the distribution of all objects that actively participate in the production process.

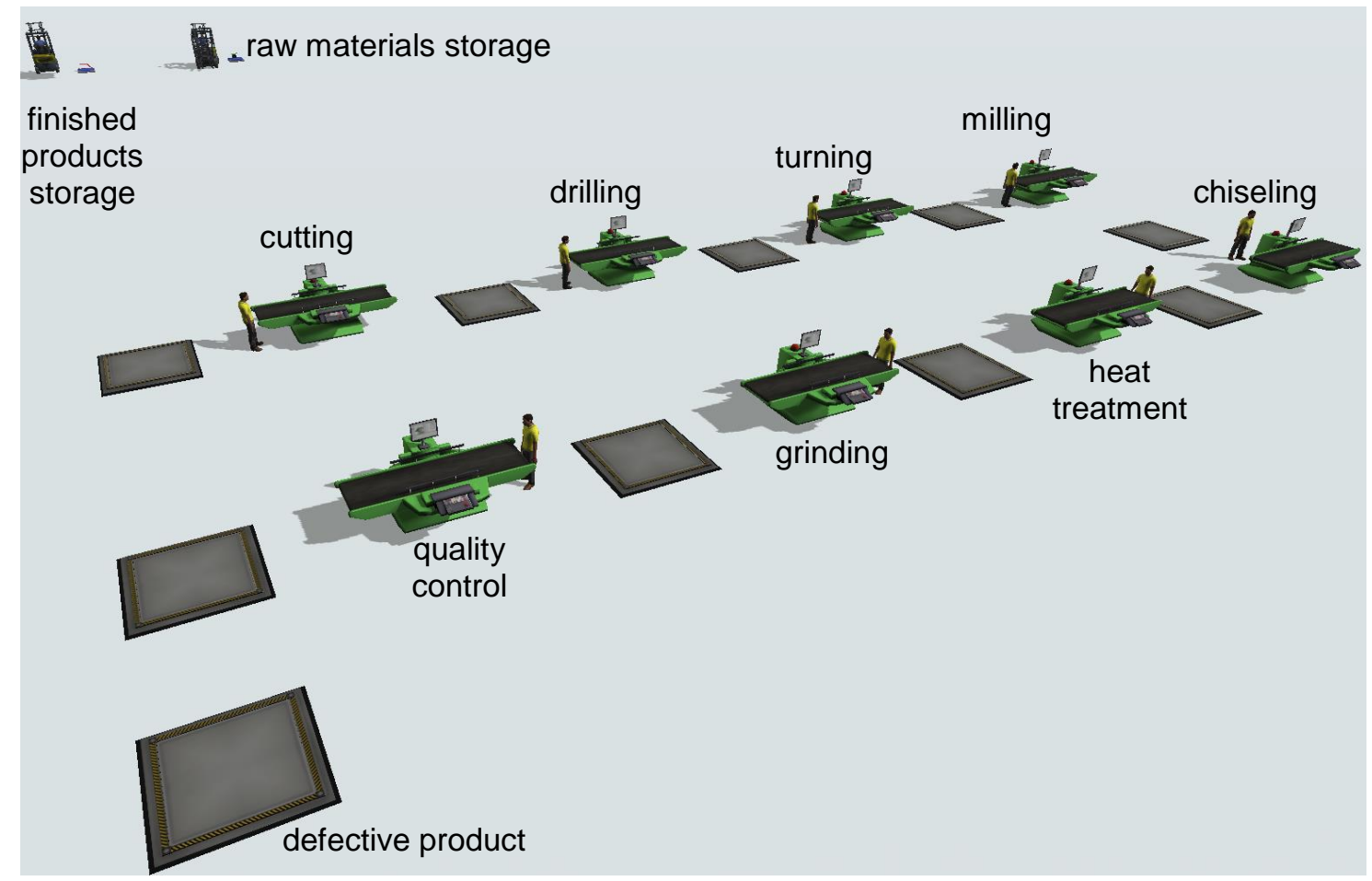

Fig. 2. Model of the analyzed production line in the FlexSim program

Source: own study

The model includes three production cycle flow of organization systems:

- serial system,

- parallel system,

- series-parallel system. 
The first step in the implementation the simulation model was the distribution of all machines on the analyzed production line, and the use an appropriate scale so that the distances between the objects in the model were kept. (Jurczyk and Wzorek, 2018). It was established that the flow element that will be generated in the model will be a box simulating the processed detail. For the purposes of the model, it was assumed that the flow elements will be generated in the amount corresponding to the size of the production batch. An object of the Source type was used to generate flow elements.

The flow elements generated by the source are then transported by a forklift truck to the first queue to the cutting station. The maximum capacity for the queue at all stations corresponded to the size of the production batch. For a model for a serial system, in the queue properties, set the option to group flow elements according to the batch size. However, in the case of simulating a serial-parallel system, the release of flow elements from the queue preceding the station with a shorter production cycle should be delayed. This can be set in the queue properties by using the appropriate flow triggers.

Quality control is carried out on the last station, which was designed with the use of a processor. The time spent by one flow element in the processor is 5 minutes. Based on historical data, the ratio of products meeting quality standards to defective products was assumed in the $99 \%$ to $1 \%$ ratio (Knop, K., 2020).

Correct products go to the queue from where they are transported by a transporter to the finished products warehouse. Products that do not meet the quality standards go to the second queue - defective products. This can be set in the processor properties by selecting "By Percentage" for the flow ports (FlexSim, 2017).

After building the simulation model and connecting all the elements, the parameters defining the duration of individual operations, the size of the production batch, the amount of work costs of a given unit and the flow of the manufactured details were defined. The amount of the labor cost of the selected production position was calculated on the basis of the analysis of the departmental, general management and theoretical costs resulting from the assumed selling price of the manufactured element and the purchase price of raw materials. In the case under consideration, the cost of work or downtime for one production station was fixed at $50 \mathrm{PLN} / \mathrm{hour}$.

\section{ANALYSIS OF SIMULATION RESULTS}

The simulations were carried out for three selected flow organization systems: serial, parallel and series-parallel systems, and various sizes of production batches. Figure 3 shows the production schedule for a batch of 10 products, at different production cycles. A series waveform occurs when a batch of parts being machined is transferred in full to the next operation only after all the work on the preceding operation is completely completed (Fig. 3a). The parallel course is characterized by the fact that the transport batches are transferred to the next operation immediately after the completion of the previous operation (Fig. 3b). If the size of the unit times of individual operations is different, there will be a full load of the stations performing the most time-consuming operation, while in the case of less labor-intensive operations there will be breaks.

The series-parallel course is characterized by the fact that each subsequent operation begins before the work on the preceding operation is fully completed, with the entire batch of parts going through each operation without any interruptions (Fig. 3c). The start time for the next batch operation may vary depending on whether the operation execution time is shorter than the preceding operation or longer. Two cases result from this: 
- if the next operation is a shorter operation than the previous one, it can start at such a time that when all the pieces are processed in the previous operation, there is still one transport batch for the next operation,

- if the next operation is longer than the previous operation, it can be started after one transport batch has been made on the previous operation.

a)

$\square$ cutting $\square$ drilling $\square$ turning $\square$ milling $\square$ chiselling $\square$ heat treatment $\square$ grinding $\square$ quality control Total Input

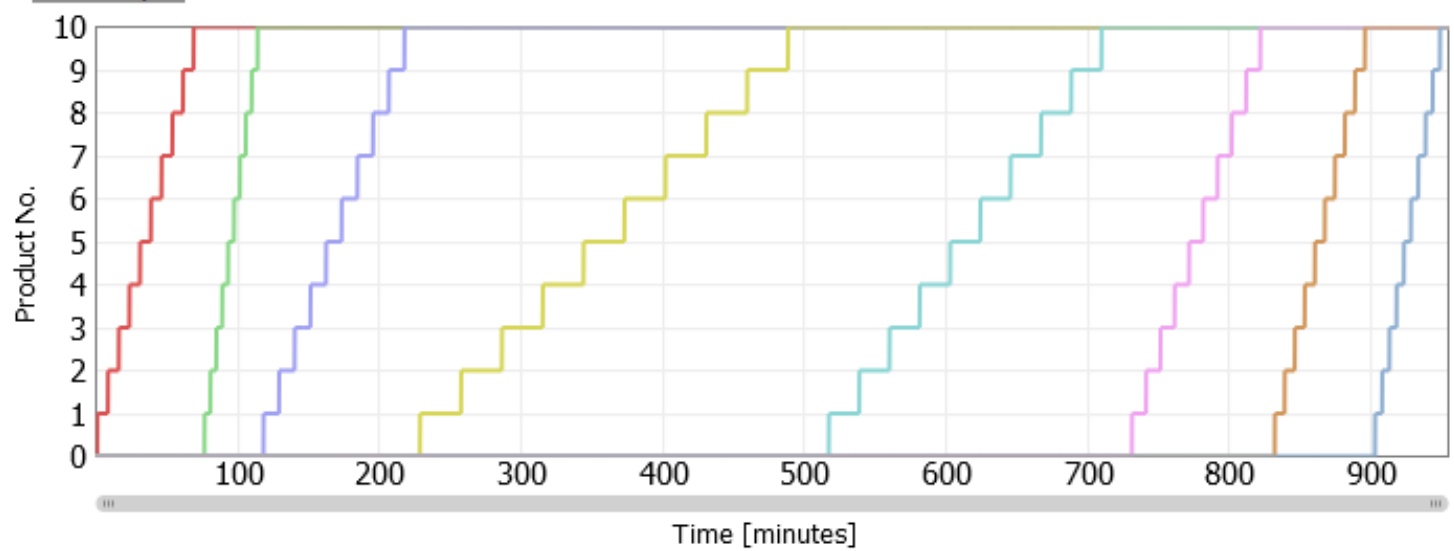

b)

$\square$ cutting $\square$ drilling $\square$ turning $\square$ milling $\square$ chiselling $\square$ heat treatment $\square$ grinding $\square$ quality control Total Input

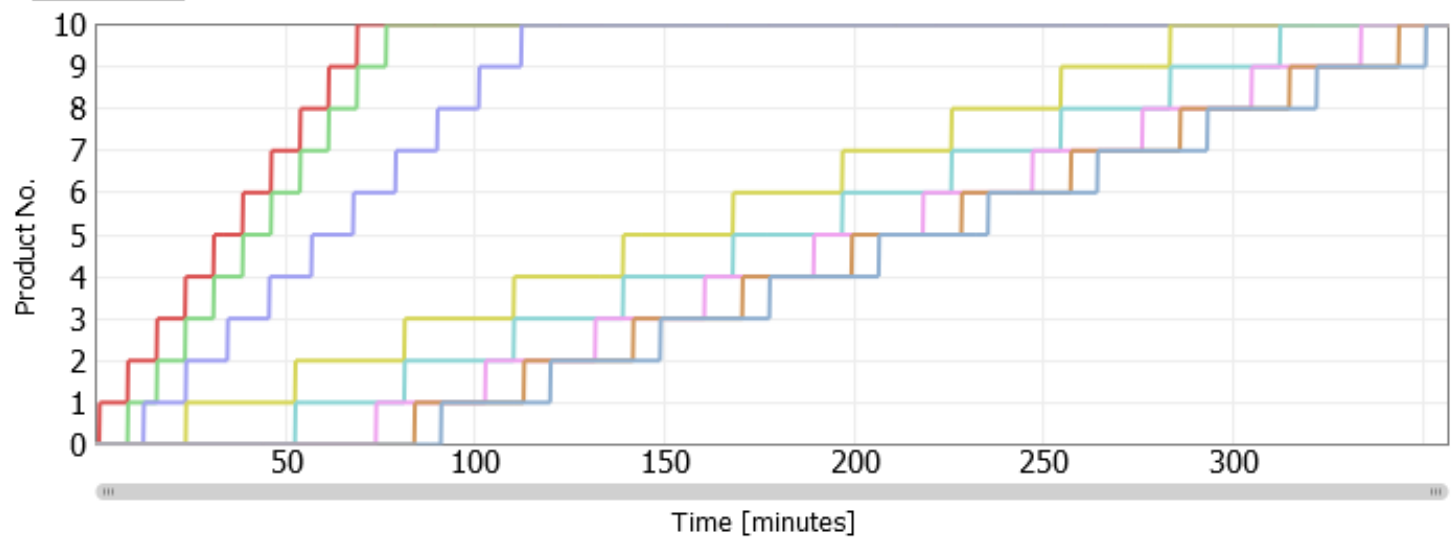

c)

$\square$ cutting $\square$ drilling $\square$ turning $\square$ milling $\square$ chiselling $\square$ heat treatment $\square$ grinding $\square$ quality control Total Input

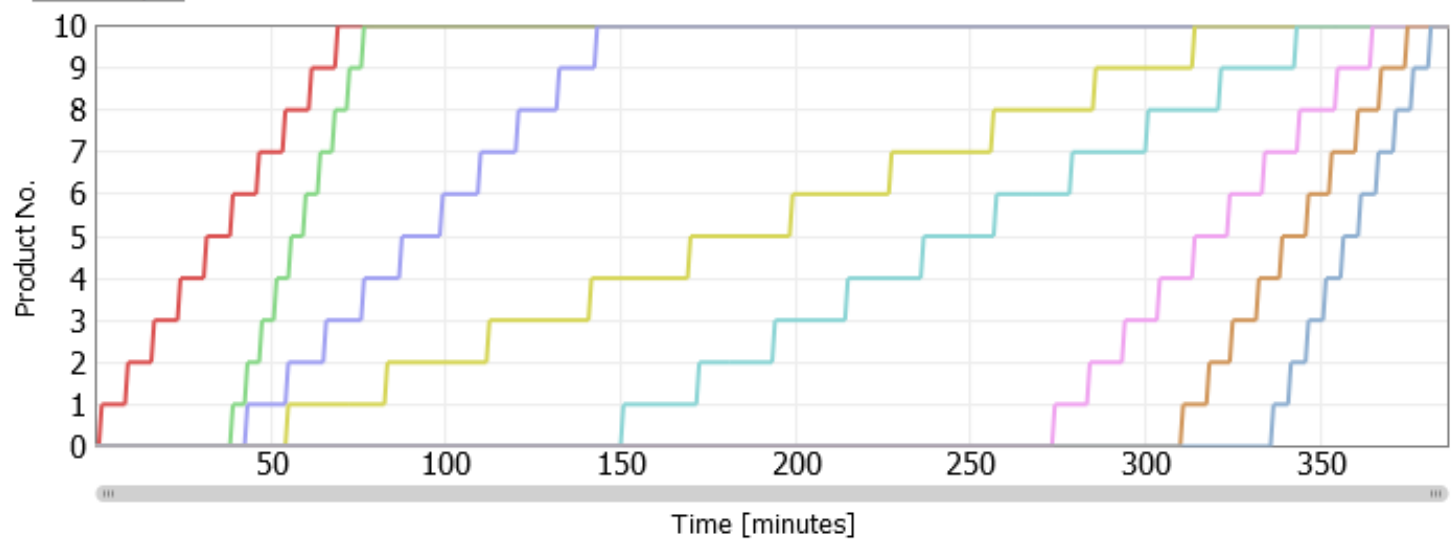

Fig. 3. Product flow cyclogram at individual work stations for a batch of 10 products: a) for a series cycle, b) for a parallel cycle, c) for a series-parallel cycle

Source: own study 
Figure 4 presents a graph showing the degree of use of individual stations during the implementation of 10 items of products. It can be seen that the milling station is characterized by the highest load.

a)

\begin{tabular}{|c|c|c|c|c|c|}
\hline \multicolumn{6}{|c|}{$\square$ processing $\square$ waiting for operator $\square$ idle } \\
\hline & $79 \%$ & בו & & & \\
\hline drilling & $43 \%$ & 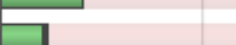 & & & \\
\hline turning & $11.5 \%$ & 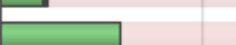 & & & \\
\hline milling & $30.2 \%$ & & & & \\
\hline chiselling & $22.3 \%$ & 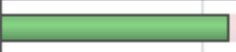 & & & \\
\hline heat treatment & $10.5 \%$ & \begin{tabular}{|l|l} 
\\
\end{tabular} & & & \\
\hline grinding & $7.3 \%$ & $\square$ & & & \\
\hline quality control & $5.2 \%$ & 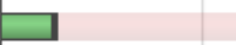 & & & \\
\hline
\end{tabular}

b)

$\square$ processing $\square$ waiting for operator $\square$ idle

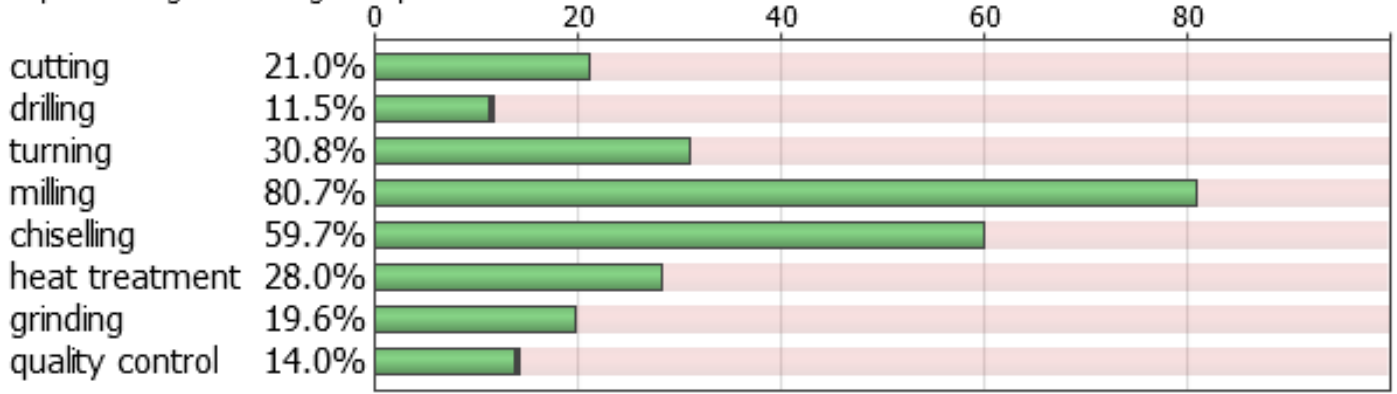

c)

$\square$ processing $\square$ waiting for operator $\square$ idle

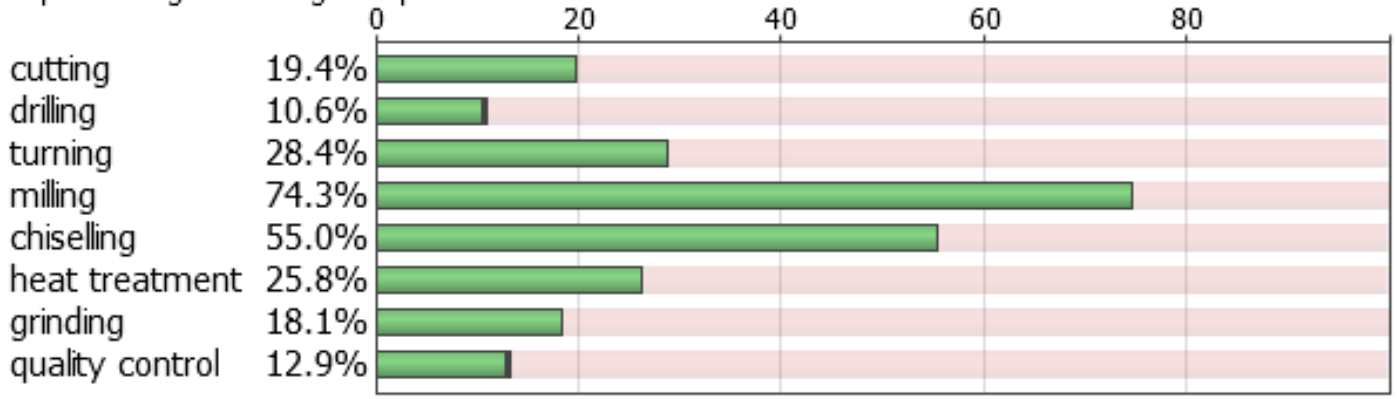

Fig. 4. The workstation efficiency for a batch of 10 products for cycle: a) serial, b) parallel, c) series-parallel

Source: own study

Based on the obtained results analysis, it was found that the use of serial flow causes a percentage decrease in the use of all production stations in relation to the total duration of the production process (including the time of execution of all technological, transport and inter-operational storage operations).

The impact of individual batch sizes and the type of flow used on the production time and cost of production are shown in Figure 5. The presented results clearly indicate that in the production of 10 and 100 pieces of elements, parallel and series-parallel flow enables the production of the entire batch in the shortest time (Fig. 5a). The shortening of the production cycle completion time is due to the lack of long-term interruptions in 
the production process resulting from the waiting of the workplace for the completion of previous operations.

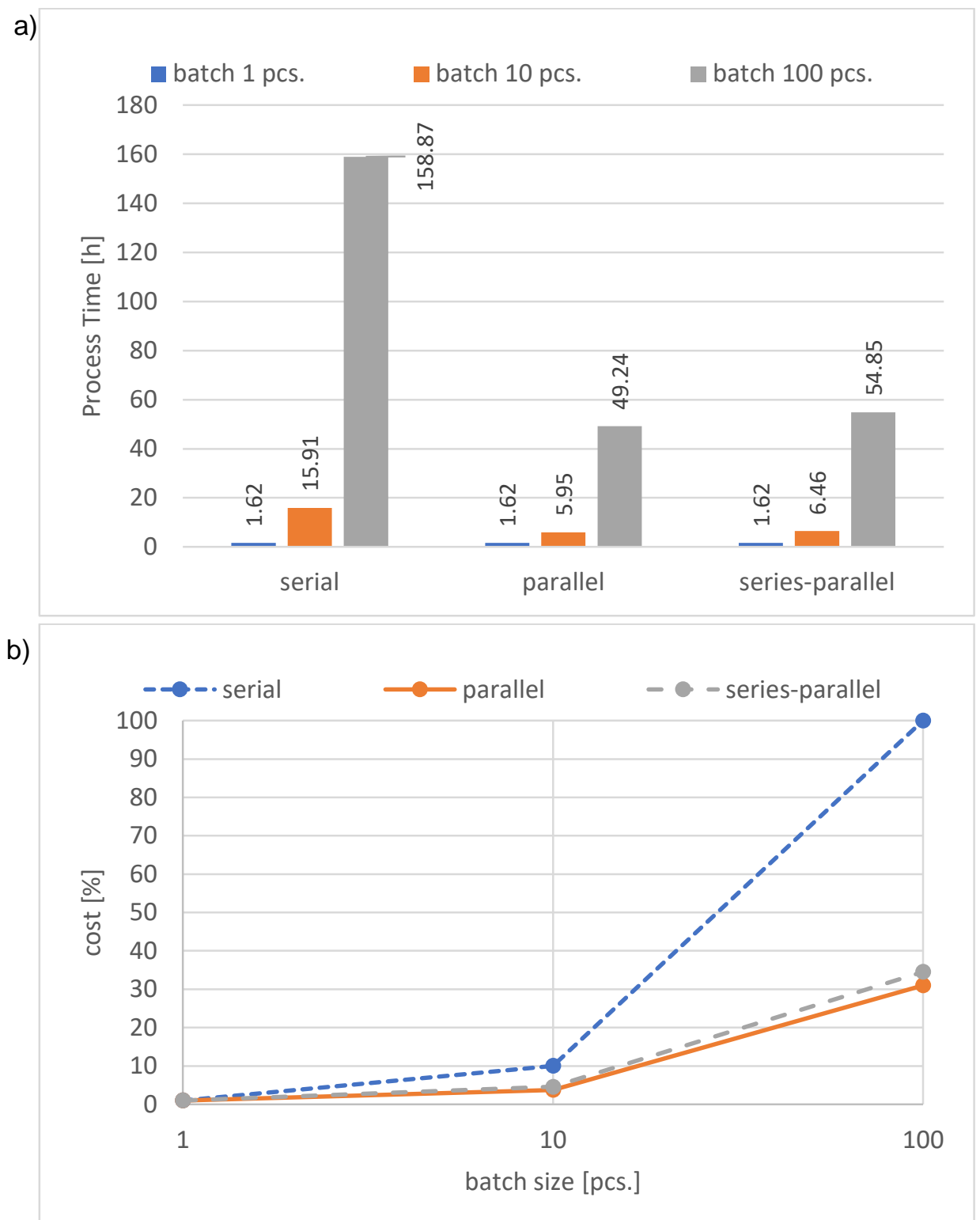

Source: own study

Fig. 5. Production process time (a), production cost (b)

Due to the direct influence of the production process time on the level of generated costs, the most economically advantageous (generating the lowest costs) was the parallel flow, Fig.5b. For comparison, with the production of 10 and 100 pieces, the cost of using serial flow in the production process will be more than twice as high as in the case of parallel flow.

In the case of parallel and series-parallel flow, the percentage degree of use of the stands is higher for the implementation of 100 items than for the production of 10 items (Fig. 6). This phenomenon is caused by a decrease in the percentage waiting time of the first working station (cutting) for the delivery of the input material (Pawlak and Nowacki, 2017). 


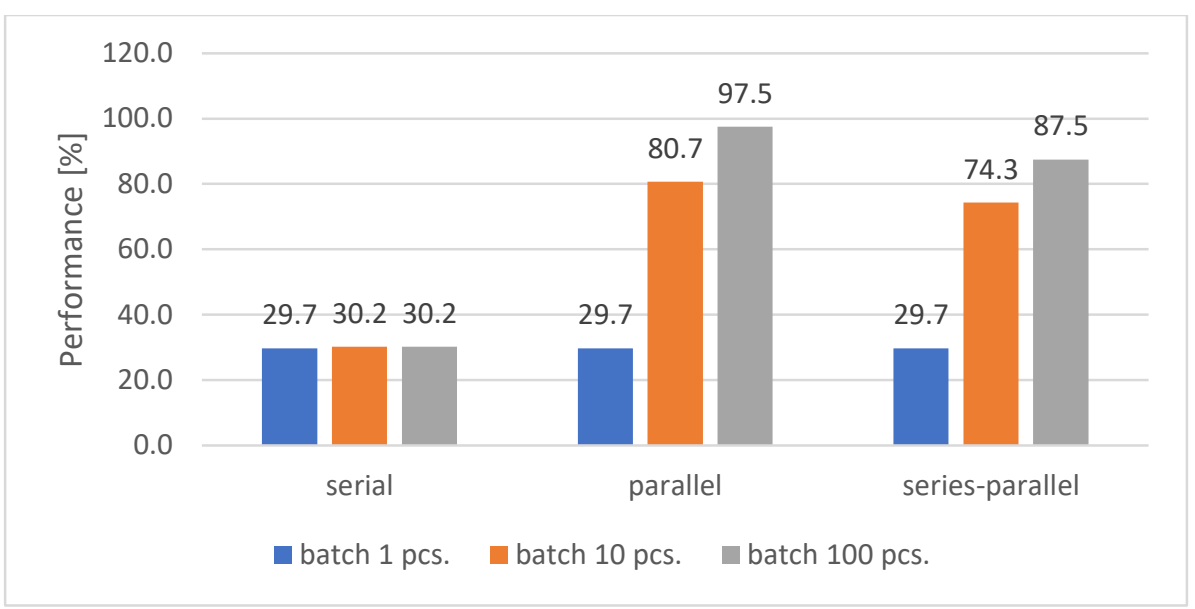

Fig. 6. The load on the workstation for the longest production cycle

Source: own study

\section{CONCLUSION}

Owing to the use of the FlexSim program, it was possible to build a model of the entire production line, which made it possible to analyze the load of machines during production and the load of buffers located between the machines. The built model enables checking various production solutions and testing potential problem-solving possibilities.

Important conclusions can be drawn from the simulation that can be used to improve the analyzed process. In the case under consideration, for the production of 10 and 100 pieces of elements (assuming that only one batch of elements is produced, with no breaks for other works), the parallel flow turned out to be the most advantageous, it ensured the shortest duration of the manufacturing process while minimizing costs. However, it should be taken into account that the complexity of the production process and in many cases its uniqueness make it difficult to formulate a thesis clearly indicating which of the tested types of flow is the most beneficial, because it depends on the specificity of the production plant and the strategy adopted by it defining specific priorities.

\section{REFERENCES}

Bartnicka, J., Kabiesz, P., Kaźmierczak, J., 2020. Standardization of human activities as the component of a workflow efficiency model - a research experiment from a meat producing plant. Production Engineering Archives, 26(2), 73-77.

Beaverstock, M., Greenwood, A.G., Lavery, E., Nordgren, B., 2012. Applied Simulation: Modeling and Analysis Using FlexSim, FlexSim Software Products.

Cegłowski, C., 2006. Business process modeling using simulation software, Bydgoszcz: Polish Association for Knowledge Management, 4-14.

Fíla, O., Sellner, K., Vysloužilová, D., Klimecka-Tatar, D., 2020. Safety and Automatization of Machining Line. System Safety: Human - Technical Facility Environment, 2(1), 268-274.

FlexSim, 2017. User manual.

Gola, A., Korzan A., 2011. Elementy komputerowo wspomaganego procesu sterowania produkcją z wykorzystaniem kart Kanban, Bzdyra, K., Informatyczne Systemy zarządzania, Wydawnicto Uczelniane Politechniki Koszalińskiej, 39-51. 
Gołda, G., Kampa, A., 2009. Modelowanie i symulacja przepływu produkcji w zrobotyzowanym gnieździe wytwórczym, Zarządzanie Przedsiębiorstwem, 1, 22-29.

Herma S., 2011. Harmonogramowanie linii montażowej jako element projektowania cyfrowej fabryki, Bzdyra, K., Informatyczne Systemy zarządzania, Wydawnicto Uczelniane Politechniki Koszalińskiej, 52-65.

Jakubowski J., Weretko, D. 2010. Przykłady wirtualnych środowisk wytwarzania na tle zarządzania rozwojem produktu, Bzdyra, K., Bocewicz, G., Informatyczne Systemy zarządzania, Wydawnicto Uczelniane Politechniki Koszalińskiej, 27-38.

Jurczyk, K., Wzorek, A., 2018. Modelowanie i symulacja systemów produkcyjnych przy wykorzystaniu oprogramowania FlexSim - studium przypadku, Studies \& Proceedings of Polish Association for Knowledge Management, 87, 4-20.

Kapustka, K., Ziegmann, G., Klimecka-Tatar, D., Nakonczy, S., 2020. Process Management and Technological Challenges in the Aspect of Permanent Magnets Recovery - the Second Life of Neodymium Magnets, Manufacturing Technology, 20(5), 617-624

Klimecka-Tatar, D., 2018. Context of production engineering in management model of Value Stream Flow according to manufacturing industry, Production Engineering Archives, 21(7), 32-35.

Knop, K., 2020. Indicating and analysis the interrelation between terms - visual: management, control, inspection and testing, Production Engineering Archives, 26(3), 110-120.

Krenczyk, D., 2018. Planowanie przepływu produkcji z uwzględnieniem ograniczeń systemu transportu wewnętrznego wspomagane systemami symulacyjnymi, Knosala, R., Innowacje w zarządzaniu i inżynierii produkcji, tom I, Oficyna Wydawnicza Polskiego Towarzystwa Zarządzania Produkcją, Opole, 441-451.

Krynke, M., Mielczarek, K., 2018. Applications of linear programming to optimize the cost-benefit criterion in production processes, MATEC Web of Conferences, Vol.183, 6s.

Le, T.D.C.,Nguyen, D.D., Oláh, J., Pakurár, M., 2020. Optimal vehicle route schedules in picking up and delivering cargo containers considering time windows in logistics distribution networks: A case study, Production Engineering Archives, 26(4), 174184

Leks D., Gwiazda A., 2015. Application of FlexSim for modelling and simulation of the production process, Selected Engineering Problems, 6, 51-56.

Mielczarek, K., 2019. An Identification of Areas Requiring Improvement in the Company Producing the Illumination - Case Study, Conference Quality Production Improvement - CQPI, 1(1), 520-527.

Pawlak, S., Nowacki, K., 2017. Wpływ parametrów systemu produkcyjnego na koszty i czas trwania procesu, Knosala, R., Innowacje w zarządzaniu i inżynierii produkcji, tom I, Oficyna Wydawnicza Polskiego Towarzystwa Zarządzania Produkcją, Opole.

Świder, J., Zdanowicz, R. 2005. Modelowanie i symulacja systemów produkcyjnych w programie Enterprise Dynamics, Wydawnictwo Politechniki Śląskiej, Gliwice.

Ulewicz, R., Mazur, M., 2019. Economic aspects of robotization of production processes by example of a car semi-trailers manufacturer, Manufacturing Technology, 19(6),1054-1059. 